\title{
Physiological mechanisms of pregnancy recognition in ruminants
}

\author{
F. W. Bazer*, W. W. Thatcher, P. J. Hansen, M. A. Mirando*, T. L. Ott* \\ and C. Plante \\ * Animal and Dairy Science Departments, University of Florida, Gainesville, Florida 32611-0691. \\ USA
}

\begin{abstract}
Summary. Maternal recognition of pregnancy in sheep, cattle and goats involves physiological mechanisms that result in protection of corpora lutea from luteolysis by modification or inhibition of uterine production of luteolytic pulses of prostaglandin (PG) F-2 $\alpha$. Ovine, bovine and caprine luteal cells release oxytocin in a pulsatile manner during late dioestrus. Oxytocin then binds to its endometrial receptors and initiates luteolytic pulses of PGF-2 $\alpha$. Ovine, bovine and caprine trophoblast protein-1 (oTP-I, bTP-1 and cTP-1) are secreted by the trophectoderm of conceptuses between Days 10 and 21-24 of pregnancy. These antiluteolytic proteins (oTP-1 and bTP-1) are primarily responsible for inhibiting uterine production of luteolytic amounts of PGF-2 $\alpha$. During early pregnancy, the numbers of endometrial receptors for oxytocin are signficantly lower in ewes and cows, and stimulatory effects of exogenous oxytocin on uterine production of PGF-2 $\alpha$ are correspondingly reduced or absent for ewes, cows and goats. Exogenous oestrogens can, through a uterine-dependent mechanism, stimulate synthesis of endometrial receptors for oxytocin and uterine production of PGF-2 $\alpha$; an effect which is significantly attenuated during early pregnancy. These results suggest that oTP-1, bTP-1 and possibly cTP-1 exert their antiluteolytic effect(s) by: (1) inhibiting effects of oestrogen and/or progesterone necessary for synthesis of endometrial receptors for oxytocin; (2) inhibiting endometrial synthesis and/or recycling of oxytocin receptors directly; or (3) inducing the endometrium to synthesize an inhibitor of an enzyme(s) necessary for synthesis of PGF-2 $\alpha$.
\end{abstract}

Keywords: pregnancy; ruminants; conceptus interferons; corpus luteum; prostaglandins; oxytocin

\section{Introduction}

Sheep, cattle and goats are species in which females have uterine-dependent ovarian oestrous cycles. In the absence of functional endometrium, there is no local endogenous source of prostaglandin (PG) F-2 $\alpha$, the uterine luteolytic agent that causes structural and functional demise of the $\mathrm{CL}$. The endocrinology responsible for uterine production of luteolytic amounts of PGF-2 $\alpha$ is complex. Progesterone from $\mathrm{CL}$ and oestradiol from ovarian follicles appear to be responsible for development of endometrial receptors for oxytocin. Oxytocin is released from the posterior pituitary and CL of sheep, cattle and goats in a pulsatile manner and interacts with its endometrial receptors to stimulate episodic secretion of PGF-2 $\alpha$ essential for luteolysis. Large and small luteal cells of sheep have high and low affinity receptors for PGF-2 $\alpha$, respectively (Balapure et al., 1989); therefore, high concentrations of PGF- $2 \alpha$ in plasma during episodic release may be required to induce luteolysis in large and small luteal cells in ruminants.

Conceptuses (embryos and associated membranes) of ruminants secrete antiluteolytic proteins (ovine trophoblast protein-1, oTP-I; bovine trophoblast protein-I, bTP-I and caprine trophoblast 
proteins, cTP), as well as luteal protective agents such as PGE-2. The proteins oTP-1, bTP-1 and possibly cTP have high amino acid sequence homology with interferons of the alpha II class (IFN $\alpha$ ) and are antiluteolytic since they modify uterine production of PGF- $2 \alpha$ to inhibit luteolysis. Luteal protective agents, such as PGE, may act at the level of the CL to inhibit luteolytic effects of PGF$2 \alpha$. Progesterone is essential for maintenance of a uterine environment supportive of conceptus development.

\section{Sheep}

\section{Luteolytic mechanism}

Endometrium of cyclic ewes releases PGF-2 $\alpha$ in a pulsatile manner between Days 15 and 17 of the cycle with at least 5 episodes of PGF-2 $\alpha$ in $24 \mathrm{~h}$ associated with luteolysis (Zarco et al., 1988). McCracken et al. (1984) proposed that oestradiol from ovarian follicles induces endometrial oxytocin receptors and that oxytocin stimulates uterine secretion of luteolytic pulses of PGF-2 $\alpha$. Oxytocin from the posterior pituitary and CL appears to control pulsatile secretion of PGF- $2 \alpha$ by uterine endometrium (Flint \& Sheldrick, 1986; Hooper et al., 1986) by stimulating the phosphatidylinositol (PI)-protein kinase C system (Flint et al., 1986). A temporal sequence of oestradiolinduced events leading to luteolysis in ewes has been described by Hixon \& Flint (1987), Administration of $500 \mu \mathrm{g}$ oestradiol to ewes on Day 10 of the oestrous cycle resulted in: (1) increased numbers of endometrial receptors for oxytocin by $12 \mathrm{~h} ;(2)$ increased oxytocin-induced PI turnover by $24 \mathrm{~h}$; (3) episodic secretion of PGF- $2 \alpha$ at $35 \pm 3 \mathrm{~h}$; (4) declining concentrations of progesterone in plasma at $42 \pm 3 \mathrm{~h}$; and (5) oestrous behaviour at $69 \pm 7 \mathrm{~h}$. Secretion of oxytocin by $\mathrm{CL}$ was first detected at $26 \pm 3 \mathrm{~h}$ or about $9 \mathrm{~h}$ before detection of a luteolytic pulse of PGF- $2 \alpha$.

Endocrine events during the oestrous cycle prepare the uterus to secrete luteolytic pulses of PGF-2 $\alpha$. The large luteal cells are responsible for transcriptional (Days $0-3$ ) and translational (Days 3-6) events which lead to storage of oxytocin in secretory granules (see Flint \& Sheldrick. 1986). Endometrial receptors for oxytocin are present early in the oestrous cycle (Days 0-3), decline and remain low until Day 13 and then increase to their highest numbers at oestrus (McCracken et al., 1984; Flint \& Sheldrick, 1986). Progesterone is essential for development of endometrial responsiveness to oxytocin; however, oestradiol, in concert with progesterone, enhances endometrial response to oxytocin (Homanics \& Silvia, 1988; Vallet \& Bazer, 1989) and synthesis of oxytocin receptors (Vallet et al., 1989). Smith et al. (1976) detected a significant increase in concentrations of oestradiol in plasma of ewes on Days 12 and 13 and Kittok \& Britt (1977) reported premature luteolysis in ewes treated with oestradiol on Days 11 and 12 or Days 12 and 13 of the oestrous cycle. Furthermore, passive immunization of ewes against oestradiol and destruction of ovarian follicles by irradiation result in prolonged luteal maintenance (see Flint \& Sheldrick, 1986).

Available results (see Bazer, 1989) suggest that the following sequence of events results in luteolysis: (1) follicular oestrogens stimulate endometrial phospholipase $\mathrm{A}_{2}$ and uterine production of subluteolytic pulses of PGF-2 $\alpha$ on Days 13 and 14; (2) subluteolytic pulses of PGF-2 $\alpha$ stimulate release of oxytocin from $\mathrm{CL}$ which acts on endometrial oxytocin receptors to stimulate uterine production of luteolytic pulses of PGF-2 $\alpha$ on Days 14 to 16; and (3) CL undergo luteolysis and ewes return to oestrus on Day 16 or Day 17.

\section{Antiluteolytic effects of the conceptus}

Pregnant ewes fail to experience luteolysis in response to doses of oxytocin and oestradiol that are luteolytic in cyclic ewes (see Bazer, 1989). Releases of oxytocin- and oxytocin-neurophysin are either reduced (Moore et al., 1982) or not different (Hooper et al., 1986) in pregnant compared to cyclic ewes between Days 13 and 16 after oestrus. A consistent finding has been that oxytocin receptor numbers are very low or absent in pregnant ewes (see Flint \& Sheldrick, 1986). Basal 
secretion of PGF-2 $\alpha$ by sheep endometrium is not reduced during pregnancy; however, pulsatile release of PGF-2 $\alpha$ is inhibited during pregnancy (see Bazer, 1989). Therefore, the conceptus is assumed to exert its antiluteolytic effect on the endometrium by inhibiting pulsatile secretion of luteolytic amounts of PGF-2 $\alpha$.

\section{What is the antiluteolytic agent secreted by sheep conceptuses?}

Moor \& Rowson (1966a, b) established that homogenates of sheep conceptuses would, when infused into the uterine lumen, but not the utero-ovarian venous drainage, extend the interoestrous interval in ewes. Ellinwood et al. (1979) determined that sheep conceptus homogenates did not contain either chorionic gonadotrophin-like or prolactin-like proteins. In-vitro culture of Day-16 sheep conceptuses and analysis of radiolabelled proteins resulted in identification of ovine trophoblast protein-1 (oTP-1), the first major protein secreted by mononuclear cells of the ovine trophectoderm (see Bazer, 1989).

oTP- 1 is secreted initially between Days 10 and 21 of pregnancy, has a molecular weight of 19000 and binds to endometrial receptors (see Bazer, 1989). There is a second period of secretion of immunoreactive oTP-1 by chorion between Days 25 and 45 of pregnancy (Ott et al., 1989b). oTP-1 has high amino acid sequence homology with interferons of the alpha-II class (Imakawa et al., 1987; Stewart et al., 1987; Charpigny et al., 1988) and potent antiviral activity (Pontzer et al., 1988). Infusion of purified oTP-1 into the uterine lumen from Days 12 to 14 extends the interoestrous interval and CL lifespan; therefore, oTP-I is assumed to exert its antiluteolytic effect on the endometrium by inhibiting the oxytocin-induced pulsatile secretion of PGF-2 $\alpha$ which causes luteolysis in ewes (see Bazer, 1989). oTP-1 does not appear to act directly on the CL to influence its lifespan or level of progesterone production (Godkin et al., 1984).

\section{Antiluteolytic effects of oTP-1}

Antiluteolytic activity in total ovine conceptus secretory proteins (oCSP) and purified oTP-1 are equal in their ability to inhibit uterine production of PGF- $2 \alpha$ in response to both oestradiol and oxytocin. However, neither oCSP minus oTP-1 nor serum had antiluteolytic activity. These results suggest that oTP-1 is the only antiluteolytic protein secreted by sheep conceptuses at Day 16 of pregnancy (see Bazer, 1989).

\section{What is the mechanism of action of oTP-1?}

oTP-1 does not compete with oxytocin for its receptor, inhibit oxytocin stimulation of endometrial phosphatidylinositide turnover or inhibit oxytocin stimulation of endometrial secretion of PGF-2 $\alpha$ in an endometrial perfusion system (see Vallet et al., 1989), which suggests that oTP-1 does not interfere with the ability of oxytocin to bind to its endometrial receptors and stimulate its second messenger system.

Secretion of oTP-1 (ng/uterine flushing) begins on about Day 10 (Ashworth \& Bazer, 1989) and increases as conceptuses change morphologically from spherical (312 ng), to tubular (1380 ng) to filamentous (4455 ng) forms (Nephew et al., 1989). Secretion of oTP-1 before initiation of synthesis of oxytocin receptors may be necessary to allow oTP-1 to prevent synthesis of oxytocin receptors and uterine secretion of luteolytic pulses of PGF-2 $\alpha$. Turnover of phosphatidylinositol (Mirando et al., 1990) and PGF-2 $\alpha$ secretion (Vallet et al., 1989) in response to oxytocin are inhibited when endometrium of cyclic ewes is exposed to oTP-1 on Days 12 through 14. Functional endometrial receptors for oxytocin are either absent or present in low numbers of pregnant ewes when measured directly (see Flint \& Sheldrick, 1986) or indirectly by the inability of oxytocin to stimulate phosphatidylinositol turnover (Mirando et al., 1990). It seems likely, therefore, that o'TP-1 may inhibit synthesis of oxytocin receptors. Interferons can inhibit synthesis, turnover or movement of receptors 
within membranes in other systems (Faltynek et al., 1984; Taylor-Papadimitriou \& Rozengurt, 1985).

Temporal changes in endometrial receptors for progesterone during the oestrous cycle and early pregnancy of sheep have not been described. However, oestrogen receptor concentrations in endometrium are lower in pregnant ewes on Days 9, 13 and 15, but not Day 11 (Findlay et al., 1982). Since progesterone and oestradiol are responsible for induction of endometrial receptors for oxytocin, as discussed previously, altered concentrations of oestrogen and/or progesterone receptors may influence conceptus-mediated antiluteolytic mechanisms. Intrauterine infusion of oCSP increases progesterone receptors about $40 \%$ (M. A. Mirando, R. J. Moffatt, T. L. Ott \& F. W. Bazer, unpublished results), which may enhance antiluteolytic effects of oTP-1 (Ott et al., 1989a).

\section{Endometrial receptors for oTP-1 and recombinant interferons}

High-affinity, low-capacity binding sites for oTP-1 are present in endometrial membranes (Godkin et al., 1984) and human interferon alpha will displace oTP-1 from those receptors (Stewart et al, 1987). Knickerbocker \& Niswender (1989) examined oTP-1 receptors in sheep endometrium. Unoccupied oTP-1 receptors were similar for cyclic and pregnant ewes on Days 8 and 12, but decreased thereafter for pregnant ewes. Hansen et al.(1989) suggested that sheep endometrium has high-and low-affinity receptors for oTP-1, but only high-affinity receptors for recombinant bovine IFN $\alpha_{1} I$ (rbIFN $\alpha$ ). Antiluteolytic effects of oTP-1 may require that it bind to both types of receptor and this may explain why oTP-1 has greater antiluteolytic activity than rbIFNa. Intrauterine infusion of rbIFN $\alpha$ extended interoestrous intervals of ewes to greater than 19 days when $2000 \mu \mathrm{g}$, but not $200 \mu \mathrm{g}$, were infused over each 24-h period from Days 9 through 19 (Stewart et al., 1989). Intrauterine infusion of oTP-1 is considerably more effective than rbIFN $\alpha$ (Stewart et al., 1989) and human IFNa $\mathrm{I}_{2} \mathrm{I}(\mathrm{rhIFN} \alpha$ ) (Davis \& Ott, 1989) in extending interoestrous intervals of sheep, suggesting that antiluteolytic properties of oTP-1 are not shared equally with rbIFN $\alpha$ and rhIFN $\alpha$.

Salamonsen et al. (1989) demonstrated that sheep endometrial cells respond to both oTP-I and rhIFN $\alpha$ in vitro with attenuated production of PGF-2 $\alpha$ and enhanced secretion of endometrial proteins. Danet-Desnoyers (1989) extended their results and demonstrated that oTP-1 inhibits oxytocin stimulation of PGF-2 $\alpha$ production by endometrial epithelium after the cells were exposed to oTP-1 for more than $10 \mathrm{~h}$.

\section{Luteal protective agents}

Concentrations of PGE in utero-ovarian vein plasma of pregnant ewes increase on Days 13 and 14 and PGE may play a luteal protective role (Silvia et al., 1984). Since PGE stimulates release of oxytocin from luteal cells, it may initiate and/or accelerate depletion of luteal oxytocin before endometrial receptors for oxytocin are maximal. This may explain pulses of oxytocin with lower amplitude in pregnant ewes (Fairclough et al., 1984). Mapletoft et al. (1976) indicated that a factor(s) in uterine venous blood delays luteolysis in ewes and Pratt et al. (1977) suggested that PGE may be that factor.

\section{Cattle}

Corpus luteum lifespan in recipient cows and ewes is extended following interspecies reciprocal transfer of trophoblastic vesicles (Martal et al., 1984), indicating similar antiluteolytic signals from conceptuses of these species. Bovine conceptuses produce bovine trophoblast protein-1 (bTP-1), which cross-reacts immunologically with oTP-1 (Helmer et al., 1987), has high amino acid sequence homology with both oTP-1 and IFN $\alpha$ (Imakawa et al., 1989) and possesses antiviral activity (Godkin et al., 1988a). 
Biochemically, bTP-1 differs from oTP-1 in that it contains N-linked carbohydrates (Anthony et al., 1988; Helmer et al., 1988) that account for molecular weight variants of 22000,24000 and 26000 (Helmer et al., 1987, 1989a; C. Plante, W. W. Thatcher \& P. J. Hansen, unpublished results). The period of bTP-1 secretion has not been established, but it is maximal around Days 16-19 of pregnancy (Bartol et al., 1985). However, mRNA for bTP-1 can be detected as early as Day 12 (Farin et al., 1989) and secretion of bTP-1 increases during elongation of the conceptus (Geisert et al., 1988). The chorion may continue to secrete bTP-1 until at least Day 38 of pregnancy (Bartol et al., 1985; Godkin et al., 1988b).

When infused into the uterine lumen of cyclic cows between Days 14 and 17, bTP-1 extended functional lifespan of CL and decreased within-animal variability in concentrations of PGF- $2 \alpha$ in the posterior vena cava (Helmer et al., 1989a). Antiluteolytic effects of bTP-1 may result from inhibition of PGF- $2 \alpha$ secretion since bTP-1 decreases PGF- $2 \alpha$ secretion from endometrial explants while also inducing an intracellular inhibitor of PGF-2 $\alpha$ synthesis (Helmer et al., 1989b). This inhibitor can also be isolated from the cytosolic fraction of endometrium from pregnant cows (Basu \& Kindhal, 1987, Gross et al., 1988a). The inhibitor may inhibit cyclooxygenase since, in cellfree systems of cotyledonary microsomal preparations rich in prostaglandin-synthesizing enzymes, it blocks conversion of arachidonic acid to both PGF-2 $\alpha$ and PGE (Gross et al., 1988a). The inhibitor is non-competitive with respect to arachidonic acid substrate, protease-sensitive, precipitable with 20\% ammonium sulphate and has $M_{r}$ forms of 25000-35000 and $70000-75000$ (Gross et al., 1988a). The inhibitor appears to be distinct from peroxidase although peroxidase is presented in elevated amounts in uterine tissues from pregnant cows (Gross et al., 1988b). Peroxidase can be separated from the inhibitor during purification (T. S. Gross, W. W. Thatcher, P. J. Hansen \& G. Newton, unpublished results).

A problem with assigning a functional role to the inhibitor is the fact that it can inhibit both PGF- $2 \alpha$ and PGE synthesis. However, bTP-1 acts on endometrial explants to decrease PGF- $2 \alpha$ secretion and increase PGE secretion (Helmer et al., 1989b). Our working hypothesis is that the inhibitor is compartmentalized within the endometrium. During the oestrous cycle, the major source of endometrial PGF- $2 \alpha$ is epithelial cells while the major source of PGE is stromal cells (Fortier et al., 1988), Perhaps bTP-1 induces the inhibitor in epithelial, but not stromal, cells.

Endometrial tissues of cyclic and pregnant cattle at Day 17 after oestrus differ in their responsiveness to agents regulating prostaglandin synthesis (Danet-Desnoyers et al., 1990). Basal secretion of PGF-2 $\alpha$ is less in pregnant endometrium in the presence or absence of $\mathrm{Ca}^{2+}$. Calcium ionophore (A23187) stimulates PGF-2 $\alpha$ secretion by pregnant endometrium in the presence or absence of $\mathrm{Ca}^{2+}$, whereas endometrium from cyclic cows is more responsive to A23187 in the presence of $\mathrm{Ca}^{2+}$. Arachidonic acid availability appears limiting to prostaglandin production in pregnant endometrium since addition of phospholipase $\mathrm{A}_{2}$ (PLA-2) to endometrial cultures stimulates PGF$2 \alpha$ secretion in the presence or absence of $\mathrm{Ca}^{2+}$. Stimulation of pregnant endometrium with PLA-2 was reduced in the presence of calcium ionophore, but this effect was not detected for endometrium of cyclic cows. Stimulation of PGF-2 $\alpha$ secretion by endometrium from pregnant and cyclic cows is increased by addition of arachidonic acid. Endometrium from pregnant cows (Day 17) has less arachidonic acid bound to phospholipids than that from Day-17 cyclic cows $(66.4<143.8 \mu \mathrm{g}$ arachidonic acid in phospholipids/g endometrium; J. C. Curl \& W. W. Thatcher, unpublished observations). This decrease may be associated with development of extraembryonic membranes for which arachidonic acid from the endometrial pool is essential.

During maternal recognition of pregnancy ovarian follicular populations are altered (Guilbault et al., 1986) and follicular waves on the ovary bearing the CL, but not the contralateral ovary, are suppressed (Ginther et al., 1989). These effects may be supportive of the antiluteolytic mechanism whereby local suppression of follicular development reduces secretion of oestradiol that could otherwise stimulate uterine secretion of PGF-2a (see Thatcher et al., 1986).

Efforts have been made to determine whether the antiluteolytic effects of rbIFN $\alpha$ and bTP-1 are similar. The rbIFN $\alpha$ shares about $50 \%$ amino acid sequence homology with bTP-1 (Imakawa $e t$ 
al., 1989). Intrauterine or intramuscular administration of rbIFN $\alpha$ can extend the length of the oestrous cycle and lifespan of the CL (Plante et al., 1988, 1989). The rbIFNa is acting, at least in part, to reduce PGF-2 $\alpha$ secretion because oxytocin-induced 13,14-dihydro-15-keto PGF-2 $\alpha$ release is reduced by administration of rbIFN $\alpha$ intramuscularly or into the uterine lumen (Plante et al., 1990).

Some actions of rbIFN $\alpha$ are pharmacological. Interferons may inhibit oestradiol and testosterone secretion (Kauppila et al,, 1982; Orava et al,, 1986). In cows, rbIFN $\alpha$ causes an acute decrease in circulating concentrations of progesterone and coincident hyperthermia on the first day of injection (Newton et al., 1990; Plante et al., 1990). Subsquently, effects of rbIFNa on concentrations of progesterone and hyperthemia are decreased. Effects of rbIFN $\alpha$ on circulating concentrations of oestradiol have not been detected (Plante et al., 1990). Effects of rblFN $\alpha$ on body temperature and progesterone secretion must be considered in developing its use to increase embryonic survival.

\section{Goat}

Goat conceptuses may exert an antiluteolytic effect similar to that of sheep conceptuses. Goat conceptuses survive and extend luteal function when transferred to ewes (Warwick \& Berry, 1949) and goat conceptuses secrete proteins with biochemical characteristics similar to those of oTP-1 (Gnatek et al., 1989). The uterine luteolysin in goats is PGF-2 $\alpha$ and the conceptus interferes with oxytocin-induced pulsatile release of PGF-2 $\alpha$ (see Homeida, 1986).

Biosynthesis of oxytocin by granulosa cells of goats begins within 6-12 h after the ovulatory surge of LH (Kiehm et al., 1989) and oxytocin is present in extracts of CL from goats $(2 \mu \mathrm{g} / \mathrm{g}$ compared to 2.6 and $1.1 \mu \mathrm{g} / \mathrm{g}$ for sheep and cow $\mathrm{CL}$, respectively; see Homeida, 1986). Exogenous oxytocin results in increased PGF-2 $\alpha$ in blood and is luteolytic when administered between Days 3 and 6 of the oestrous cycle, an effect inhibited by administration of prostaglandin synthetase inhibitors (see Homeida, 1986). Luteolytic pulses of PGF-2 $\alpha$ are associated with pulses of oxytocin and its neurophysin during luteolysis in cyclic goats (see Homeida, 1986) and luteolysis can be delayed by intra-arterial administration of an oxytocin antagonist (Homeida \& Khalafalla, 1987).

Removal of goat conceptuses from the uterine lumen between Days 13 and 15 does not affect the interoestrous interval, but their removal on Day 17 does extend luteal lifespan by 7-10 days (Gnatek et al., 1989). This suggests that maternal recognition of pregnancy in goats occurs around Day 17. Between Days 16 and 21, goat conceptuses secrete cTP that can be immunoprecipitated with antiserum to oTP-1 and may be the antiluteolytic protein (Gnatek et al., 1989). However, other trophoblast proteins of higher molecular weight with basic pl values may also be involved in establishment of pregnancy in goats. Pulsatile release of oxytocin and PGF-2 $\alpha$ are suppressed in pregnant compared to cyclic goats between Days 10-12 and oestrus or Day 20 of pregnancy (see Homeida, 1986) suggesting that antiluteolytic mechanisms in the goat may be similar to those for sheep and/or cows.

These studies have been supported by grants from the National Institutes of Health (HD 10436 to F.W.B.), the United States Department of Agriculture (85-CRCR-1-1871 and 89-37240-4583 to W.W.T. and P.J.H.) and Ciba-Geigy to W.W.T. and P.J.H.

\section{References}

Anthony, R.V., Helmer, S.D., Sharif, S.F., Roberts, R.M., Hansen, P.J., Thatcher, W.W. \& Bazer, F.W. (1988) Synthesis and processing of ovine trophoblast protein-1 and bovine trophoblast protein-1, conceptus secretory proteins involved in the maternal recognition of pregnancy. Endocrinology 123, 1224-1280.
Ashworth, C.J. \& Bazer, F.W. (1989) Interrelationships of proteins secreted by the ovine conceptus and endometrium during the periattachment period. Anim. Reprod. Sci. 20, 117-130.

Balapure, A.K., Caicedo, I.C., Kawada, K., Watt, D.S., Rexroad, C.E., Jr \& Fitz, T.A. (1989) Multiple classes 
of prostaglandin $\mathrm{F}_{2} \alpha$ binding sites in subpopulations of ovine luteal cells. Biol Reprod, 41, 385-392.

Bartol, F.F., Roberts, R.M., Bazer, F.W., Lewis, G.S., Godkin, J.D. \& Thatcher, W.W. (1985) Characterization of proteins produced in vitro by periattachment bovine conceptuses. Biol. Reprod. 32, 681-693.

Basu, S. \& Kindahl, H. (1987) Inhibitor of prostaglandin biosynthesis in the bovine endometrium during estrous cycle and early pregnancy. Theriogenology 27, $212-226$.

Bazer, F.W. (1989) Establishment of pregnancy in sheep and pigs. Reprod. Fert. Dev, 1, 237-242.

Charpigny, G., Reinaud, P., Huet, J.C., Guillomot, M., Charlier, M., Pernollet, J.C. \& Martal, J. (1988) High homology between trophoblastic protein (trophoblastin) isolated from ovine embryo and $\alpha$-interferons. Fedn Eur, Biochem. Soc, 228, 12-16.

Danet-Desnoyers, G. (1989) Etude in vitro du mode d'action d'un interferon embryonnaire; la trophoblastine (oTP) inhibe syntheses de prostaglandin $\mathrm{F}_{2}$ dans les cellules endometriales. Dip. Etudes Approfondés de Physiologie de la Reproduction. Universite Pierre et Marie Curie, Paris VI, pp. 1-22.

Danet-Desnoyers, G., Gross, T.S., Thatcher, W.W. \& Johnson, J.W. (1990) Endometrial prostaglandin secretion in response to arachidonic acid (AA), $\mathrm{Ca}^{++}$, ionophore A23187 and phospholipases in cyclic and pregnant cows. Biol. Reprod. 42 (Suppl. 1). 54. abstr.

Davis, M.A. \& Ott, T.L. (1989) Comparison of effects of recombinant human interferon alpha II and ovine conceptus secretory proteins on the interestrous interval of sheep. Biol. Reprod. $\mathbf{4 0}$ (Suppl. 1), 85, abstr.

Ellinwood, W.E., Nett, T.M. \& Niswender, G.D. (1979) Maintenance of the corpus luteum of early pregnancy in the ewe. I. Luteotropic properties of embryonic homogenates. Biol. Reprod. 21, 281-288.

Fairclough, R.J., Moore, L.G., Peterson, A.J. \& Watkins, W.B. (1984) Effect of oxytocin on plasma concentrations of 13,14-dihydro-15-keto prostaglandin F and the oxytocin associated neurophysin during the estrous cycle and early pregnancy in the ewe. Biol. Reprod. 31, 36-43.

Faltynek, C.R., McCandless, S. \& Baglioni, C. (1984) Treatment of lymphoblastoid cells with interferon decreases insulin binding. J. Cell Physiol. 121, $437-444$.

Farin, C.E., Hansen, T.R., McDonnell, J.M., Murphy, C.N. \& Farin, P.W. (1989) Onset of ovine and bovine trophoblast protein-1 (oTP-1 and bTP-1) gene expression in shecp and cattle embryos. Biol. Reprod. 40 (Suppl. 1), 63, abstr.

Findlay, J.K., Clarke, I.J., Swaney, J., Colvin, N. \& Doughton, B. (1982) Oestrogen receptors and protein synthesis in caruncular and intercaruncular endometrium of sheep before implantation. I. Reprod. Fert. 64, 329-339.

Flint, A.P.F. \& Sheldrick, E.L. (1986) Ovarian oxytocin and maternal recognition of pregnancy. J. Reprod. Fert. 76, 831-839.

Flint, A.P.F., Leat, W.M.F., Sheldrick, E.L. \& Stewart, H.J. (1986) Stimulation of phosphoinositide hydrolysis by oxytocin and the mechanism by which oxytocin controls prostaglandin synthesis in the ovine endometrium. Biochem. J. 237, 797-805.
Fortier, M.A., Guilbault, L.A. \& Grasso, F. (1988) Specific properties of epithelial and stromal cells from the endometrium of cows. J. Reprod. Fert. 83, 239-248.

Geisert, R.D., Zavy, M.T., Biggers, B.G., Garret, J.E. \& Wettemann, R.P. (1988) Characterization of the uterine environment during early conceptus expansion in the bovine. Anim. Reprod. Sci. 16, 11-25.

Ginther, O.J., Kastelic, J.P. \& Knopf, L. (1989) Intraovarian relationships among dominant and subordinate follicles and the corpus luteum in heifers. Theriogenology 32, 787-795.

Gnatek, G.G., Smith, L.D., Duby, R.T. \& Godkin, J.D. (1989) Maternal recognition of pregnancy in the goat: Effects of conceptus removal on interestrus intervals and characterization of conceptus protein production during early pregnancy. Biol. Reprod. 41, 655-664.

Godkin, J.D., Bazer, F.W. \& Roberts, R.M. (1984) Ovine trophoblast protein-1, an early secreted blastocyst protein, binds specifically to uterine endometrium and affects protein synthesis. Endocrinology 114, $120-130$.

Godkin, J.D., Lifsey, B.J., Fujii, D.K. \& Baumbach, G.A. (1988a) Bovine trophoblast protein-I: purification, antibody production, uterine cell interaction and antiviral activity. Biol. Reprod. 38 (Suppl. 1), 79 abstr.

Godkin, J.D., Lifsey, B.J. \& Gillespie, B.E. (1988b) Characterization of bovine conceptus proteins produced during the peri- and postattachment periods of early pregnancy. Biol. Reprod. 38, $703-712$.

Gross, T.S., Thatcher, W.W., Hansen, P.J., Johnson, J.W. \& Helmer, S.D. (1988a) Presence of an intracellular endometrial inhibitor of prostaglandin synthesis during early pregnancy in the cow. Prostaglandins 35, 359-378.

Gross, T.S., Hansen, P.J., Thatcher, W.W., Helmer, S.D., Plante, C. \& Johnson, J.W. (1988b) Peroxidase activity and intracellular inhibitors of prostaglandin synthesis in endometrium during early pregnancy in cattle. Proc, IJth Int. Congr. Anim. Reprod. A.I., Dublin 2, 91

Guilbault, L.A., Dufour, J.J., Thatcher, W.W., Drost, M. \& Haibel, G.K. (1986) Ovarian follicular development during early pregnancy in cattle. $J$. Reprod. Fert. 78, 127-135.

Hansen, T.R., Kazemi, M., Keisler, D.H., Malathy, P.V., Imakawa, K. \& Roberts, R.M. (1989) Complex binding of the embryonic interferon, ovine trophoblast protein-1, to endometrial receptors. I. Interferon Res. 9, 215-225.

Helmer, S.D., Hansen, P.J., Anthony, R.V., Thatcher, W.W., Bazer, F.W. \& Roberts, R.M. (1987) Identification of bovine trophoblast protein-1, a secretory protein immunologically related to ovine trophoblast protein-1. J. Reprod. Fert. 79, 83-91.

Helmer, S.D., Hansen, P.J. \& Thatcher, W.W. (1988) Differential glycosylation of the components of the ovine trophoblast protein-1 complex. Molec. cell. Endocrinol. 58, 103-107.

Helmer, S.D., Hansen, P.J., Thatcher, W.W., Johnson, J.W. \& Bazer, F.W. (1989a) Intrauterine infusion of highly enriched bovine trophoblast protein-1 
complex exerts an antiluteolytic effect to extend corpus luteum lifespan in cyclic cattle. J. Reprod. Fert, 87, 89-101.

Helmer, S.D., Gross, T.S., Newton, G.R., Hansen, P.J. \& Thatcher, W.W. (1989b) Bovine trophoblast protein1 complex alters endometrial protein and prostaglandin secretion and induces an intracellular inhibitor of prostaglandin synthesis in vitro. J. Reprod. Fert. 87, 421-430.

Hixon, J.E. \& Flint, A.P.F. (1987) Effects of a luteolytic dose of oestradiol benzoate on uterine oxytocin receptor concentrations, phosphoinositide turnover and prostaglandin F-2 $\alpha$ secretion in sheep. J. Reprod. Fert. 79, 457-467.

Homanics, G.E. \& Silvia, W.J. (1988) Effects of progesterone and estradiol-17ß on uterine secretion of prostaglandin $\mathrm{F}_{2} \alpha$ in response to oxytocin in ovariectomized ewes. Biol. Reprod. 38, 804-811.

Homeida, A.M. (1986) Role of oxytocin during the oestrous cycle of ruminants with particular reference to the goat. Anim. Breed. Abstr. 54, 263-268.

Homeida, A.M. \& Khalafalla, A.E. (1987) Effects of oxytocin-antagonist injections on luteal regression in the goat. Br. J. Pharmacol. 90, 281-284.

Hooper, S.B., Watkins, W.B. \& Thorburn, G.D. (1986) Oxytocin, oxytocin associated neurophysin, and prostaglandin $F_{2} \alpha$ concentrations in the uteroovarian vein of pregnant and nonpregnant sheep. Endocrinology 119, 2590-2597.

Imakawa, K., Anthony, R.V., Kazemi, M., Marotti, K.R., Polites, H.G. \& Roberts, R.M. (1987) Interferon-like sequence of ovine trophoblast protein secreted by embryonic trophectoderm. Nature, Lond. 330, 377-379.

Imakawa, K., Hansen, T.R., Malathy, P.V., Anthony, R.V., Polites, H.G., Marotti, K.R. \& Roberts, R.M. (1989) Molecular cloning and characterization of complementary deoxyribonucleic acids corresponding to bovine trophoblast protein-1: a comparison with ovine trophoblast protein-1 and bovine interferon- $a_{11}$. Molec. Endocrinol, 3, 127-139.

Kauppila, A., Cantell, K., Janne, O., Kokko, E. \& Vihko, R. (1982) Serum sex steroid and peptide hormone concentrations, and endometrial estrogen and progesterone receptor levels during administration of human leukocyte interferon. Int. J. Cancer 29, 29I-294.

Kiehm, D.J., Walters, D.L., Daniel, S.A.J. \& Armstrong, D.T. (1989) Preovulatory biosynthesis and granulosa cell secretion of immunoreactive oxytocin by goat ovaries. J. Reprod. Fert. 87, 485-493.

Kittok, R.J. \& Britt, J.H. (1977) Corpus luteum function in ewes given estradiol during the estrous cycle or early pregnancy. J. Anim. Sci. 45, 336-34l.

Knickerbocker, J.J. \& Niswender, G.D. (1989) Characterization of endometrial receptors for ovine trophoblast protein-1 during the estrous cycle and early pregnancy in sheep. Biol. Reprod. 40, 361-370.

Mapletoft, R.J., Lapin, D.R. \& Ginther, O.J. (1976) The ovarian artery as the final component of the local luteotropic pathway between a gravid uterine horn and ovary in ewes. Biol. Reprod. 15, 414 421.

Martal, J., Camous, S., Fevre, J., Charlier, M. \& Heyman, Y. (1984) Specificity of embryonic signals maintaining corpus luteum function in early pregnancy in ruminants. Proc. 10th Int. Congr. Anim. Reprod. A.I., Urbana 3, 510.

McCracken, J.A., Schramm, W. \& Okulicz, W.C. (1984) Hormone receptor control of pulsatile secretion of $\mathrm{PGF}_{2}$ from the ovine uterus during luteolysis and its abrogation in early pregnancy. In Prosiaglandins in Animal Reproduction II, pp. 31-56. Eds L. E. Edqvist \& H. Kindahl. Elsevier, Amsterdam.

Mirando, M.A., Ott, T.L., Vallet, J.L., Davis, M.A. \& Bazer, F.W. (1990) Oxytocin-stimulated inositol phosphate turnover in endometrium of ewes is influenced by stage of the estrous cycle, pregnancy and intrauterine infusion of ovine conceptus secretory proteins. Biol. Reprod. 42, 98-105.

Moor, R.M. \& Rowson, L.E.A. (1966a) The corpus luteum of the sheep effect of the removal of embryos on luteal function. J. Endocr. 34, 497-502.

Moor, R.M. \& Rowson, L.E.A. (1966b) The corpus luteum of the sheep: Functional relationship between the embryo and the corpus luteum. J. Endocr. 34, 233-239.

Moore, L.G., Watkins, W.B., Peterson, A.J., Tervit, H.R., Fairclough, R.J., Havik, P.G. \& Smith, J.F (1982) Embryonic suppression of oxytocin-associated neurophysin release in early pregnant sheep. Prostaglandins 24, 79-88.

Nephew, K.P., McClure, K.E., Ott, T.L., Bazer, F.W. \& Pope, W.F. (1989) Cumulative recognition of pregnancy by embryonic production of ovine trophoblastic protein-one. J. Anim. Sci, 67 (Suppl. 1), 404, abstr.

Newton, G.R., Martinod, S., Hansen, P.J., Thatcher, W.W., Siegenthaler, B., Gerber, C. \& Voirol, M.-J. (1990) Interferon alpha causes acute changes in body temperature and serum progesterone concentrations in heifers. J. Dairy Sci. (in press).

Orava, M., Cantell, K. \& Vihko, R. (1986) Treatment of men with preparations of human leukocyte interferon decreases serum testosterone concentrations in men. Int. J. Cancer 38, 295-296.

Ott, T.L., Davis, M.A. \& Fliss, M.F.V. (1989a) Interaction of progesterone and ovine conceptus secretory proteins on endometrial responsiveness to oxytocin in sheep. Biol. Reprod. 40 (Suppl. 1), 85, abstr.

Ott, T.L., Mirando, M.A., Davis, M.A., Fliss, M.F.V. \& Bazer, F.W. (1989b) Characterization of a second period of immunoreactive ovine trophoblast proteinone secretion in sheep. I. Anim. Sci. 67 (Suppl. I), 370, abstr.

Plante, C., Hansen, P.J. \& Thatcher, W.W. (1988) Prolongation of luteal lifespan in cows by intrauterine infusion of recombinant bovine alpha-interferon. Endocrinology 122, 2342-2344.

Plante, C., Hansen, P.J., Martinod, S., Siegenthaler, B., Thatcher, W.W., Pollard, J.W. \& Leslie, M.V. (1989) Effect of intrauterine and intramuscular administration of recombinant bovine interferon $\alpha_{1}$ on luteal lifespan in cattle. J. Dairy Sci. 72, 1859-1865.

Plante, C., Hansen, P.J. \& Thatcher, W.W. (1990) Effect of recombinant bovine interferon-al, type I (IFN) on ovarian function, oxytocin-induced release of prostaglandin $\mathrm{F}_{2} \alpha$ metabolite (PGFM) and body temperature in cows. Biol. Reprod $\mathbf{4 2}$ (Suppl. 1), 80, abstr.

Pontzer, C.H., Torres, B.A., Vallet, J.L., Bazer, F.W. \& Johnson, H.M. (1988) Antiviral activity of the 
pregnancy recognition hormone ovine trophoblast protein-1. Biochem. Biophys. Res. Commun. 152, 801-807.

Pratt, B.R., Butcher, R.L. \& Inskeep, E.K. (1977) Antiluteolytic effect of the conceptus and of $\mathrm{PGE}_{2}$ in ewes. J. Anim. Sci. 46, 784-791.

Salamonsen, L.A., Manikhot, J., Healy, D.L. \& Findlay, J.K. (1989) Ovine trophoblast protein-I and human interferon alpha reduce prostaglandin synthesis by ovine endometrial cells. Prostaglandins 38, 289-305.

Silvia, W.J., Ottobre, J.S. \& Inskeep, E.K. (1984) Concentrations of prostaglandins $\mathrm{E}_{2}, \mathrm{~F}_{2} \alpha$ and 6-ketoprostaglandin $F_{1} \alpha$ in the utero-ovarian venous plasma of nonpregnant and early pregnant ewes. Biol, Reprod. 30, 936-944.

Smith, J.F,, Drost, H., Fairclough, R.J., Peterson, A.J. \& Tervit, H.R. (1976) Effect of age on peripheral levels of progesterone and oestradiol-17 $\beta$, and duration of oestrus in Romney Marsh ewes. N.Z. Jl agric. Res. $19,277-283$.

Stewart, H.J., McCann, S.H.E., Barker, P.J., Lee, K.E., Lamming, G.E. \& Flint, A.P.F. (1987) Interferon sequence homology and receptor binding activity of ovine trophoblast antiluteolytic protein. I. Endocr. 115, RI3-RI5.

Stewart, H.J., Flint, A.P.F., Lamming, G.E., McCann, S.H.E. \& Parkinson, T.J. (1989) Antiluteolytic effects of blastocyst-secreted interferon investigated in vitro and in vivo in the sheep. J. Reprod. Fert., Suppl, 37. $127-138$.
Taylor-Papadimitriou, J. \& Rozengurt, E. (1985) Interferons as regulators of cell growth and differentiation. In Interferons: their Impact in Biology and Medicine, pp. 8I-98. Ed. J. Taylor-Papadimitriou. Oxford University Press, Oxford.

Thatcher, W.W., Bazer, F.W., Sharp, D.C. \& Roberts, R.M. (1986) Interrelationship between uterus and conceptus to maintain corpus luteum function during early pregnancy: sheep, cattle, pigs and horses. $J$. Anim. Sci. 67 (Suppl. 2), 47-61.

Vallet, J.L. \& Bazer, F.W. (1989) The effect of ovine trophoblast protein-1, oestrogen and progesterone on oxytocin-induced phosphatidylinositol turnover in endometrium of sheep. J. Reprod. Fert. 87, $755-761$.

Vallet, J.L., Gross, T.S., Fliss, M.F.V. \& Bazer, F.W. (1989) Effects of pregnancy, oxytocin, ovine trophoblast protein-1 and their interactions on endometrial production of prostaglandin $F_{2} \alpha$ in vitro in perifusion chambers. Prostaglandins 38, 113-125.

Warwick, B.L. \& Berry, R.O. (1949) Inter-generic and intra-specific embryo transfers. $J$. Hered. 11, $297-303$.

Zarco, L., Stabenfeldt, G.H., Quirke, J.F., Kindahl, H. \& Bradford, G.E. (1988) Release of prostaglandin F-2 $\alpha$ and the timing of events associated with luteolysis in ewes with oestrous cycles of different lengths. $J$. Reprod. Fert. 83, 517-526. 
